\title{
Penerapan Metode Clustering Text Mining Untuk Pengelompokan Berita Pada Unstructured Textual Data
}

\author{
Nyoman Gede Yudiarta $^{1}$, Made Sudarma ${ }^{2}$, Wayan Gede Ariastina ${ }^{3}$
}

\begin{abstract}
Good governance was a government whose programs were known and beneficial to the people. In Bali Provincial Government which has duty in disseminating information is Bureau of Public Relations Regional Secretariat Bali through media owned. Because at the time of news input to the media in this case Public Relations Bureau website was not included causing the emergence of problems in the form of difficulty knowing the news, which news that goes into certain categories. Clustering was a method to solve the problem. One of the algorithms used in the Clustering method is the K-Means algorithm. This study focused on designing to classify news data into a category using K-Means. To process the documents obtained to make it easier in the process of clustering, was done by preprocess documents first. Document preparation consists of case folding, tokenization, filtering and stemming. Tf-Idf was done to pass the weighting of the terms obtained on the preprocessed documents. The results of experiments conducted using different amounts of data that are 50, 100, 200, 300, 400, and 500 data obtained results that the K-Means algorithm applied to cluster news, able to work and provide a satisfactory accuracy, Precision average of $70.76 \%$ while Recall of $\mathbf{7 0 . 8 6 \%}$ and Purity of 0.76 for all test data.
\end{abstract}

Intisari- Pemerintahan yang baik adalah pemerintahan yang program-programnya diketahui dan bermanfaat bagi masyarakatnya. Pada Pemerintah Provinsi Bali yang memiliki tupoksi dalam melakukan penyebarluasan informasi adalah Biro Humas Setda Provinsi Bali melalui media yang dimiliki. Dikarenakan pada saat input berita ke media dalam hal ini website Biro Humas tidak disertakan kategori menyebabkan timbulnya permasalahan berupa sulitnya mengetahui beritaberita yang mana saja yang masuk ke kategori tertentu. Clustering merupakan metode untuk mengatasi permasalahan tersebut. Salah satu algoritma yang digunakan dalam metode Clustering adalah algoritma K-Means. Penelitian ini berfokus pada perancangan untuk mengelompokan data berita ke suatu kategori dengan menggunakan K-Means. Untuk mengolah dokumen yang didapat agar lebih mempermudah dalam proses clustering, dilakukanlah preprocessing dokumen terlebih dahulu. Preprocessing dokumen terdiri dari case folding, tokenization, filtering dan stemming. Tf-Idf dilakukan untuk melalukan pembobotan terhadap term yang didapatkan pada preprocessing dokumen. Hasil coba yang dilakukan dengan menggunakan jumlah data yang berbeda yaitu 50, 100, 200, 300, 400, dan 500 data didapatkan hasil bahwa algoritma K-Means yang diterapkan untuk meng cluster berita, mampu bekerja dan memberikan akurasi yang memuaskan, dengan rata-rata

\footnotetext{
${ }^{1}$ Mahasiswa, Program Studi Magister Teknik Elektro, Jalan Dewi Supraba VI. No.23 ,Denpasar Bali INDONESIA (tlp:081916153335; e-mail: mankyudiarta@gmail.com)

2, 3 Dosen, Program Studi Magister Teknik Elektro, Jalan Panglima Besar Sudirman, Denpasar Bali Indonesia (tlp: 0361239599; fax:0361-239599; e-mail: imasudarma@gmail.com, w.ariastina@gmail.com )
}

Nyoman Gede Yudiarta: Penerapan Metode Clustering Text...
Precision sebesar 70,76\% sedangkan Recall sebesar 70,86\% serta Purity sebesar 0,76 untuk semua data uji.

\section{Kata Kunci-Clustering, K-Means, Preprocessing, Tf-Idf}

\section{Pendahuluan}

Pemerintahan yang baik adalah pemerintahan yang program - programnya diketahui dan bermanfaat bagi masyarakatnya. Masyarakat berhak mengetahui apa saja kegiatan - kegiatan yang telah dilakukan pemerintah untuk memajukan daerahnya. Semua kegiatan dan kebijakan dari mulai rencana kerja sampai hasil dipublikasikan di berbagai media yang dimiliki oleh Pemerintah antara lain melalui Website, Sosial Media seperti Facebook dan Twitter, Pentas Seni, Surat Kabar, dan TV Display.

Di dalam Web Pemerintah terdapat berita - berita yang diumumkan oleh Bagian Publikasi. Dalam hal ini pada saat melakukan input berita, tidak terdapat kategori, penggolongan ataupun pengelompokan jenis berita yang diinputkan sesuai dengan 12 program Aksi Bali Mandara, dengan tidak terdapatnya pengelompokan jenis berita pada saat melakukan input berita menyebabkan timbulnya permasalahan berupa sulitnya mengetahui berita - berita yang mana saja yang masuk ke kategori tertentu sehingga dalam mencari suatu berita dengan topik tertentu memerlukan waktu yang tidak sedikit. Untuk mempermudah dalam pengelolaan berita-berita serta pengelompokan berita yang sesuai dari beberapa dokumen yang melibatkan data text yang tidak terstruktur, maka diperlukan suatu teknik clustering. Clustering dipakai ketika tidak diketahuinya bagaimana data harus dikelompokkan. Clustering dapat digunakan untuk membantu menganalisis berita dengan mengelompokkan secara otomatis berita yang memiliki kesamaan atau kemiripan. Sebuah cluster adalah sekumpulan objek yang digabung bersama karena persamaan atau kedekatannya [1]. Clustering termasuk dalam teknik unsupervised learning dimana tidak memerlukan fase training [2].

Karena clustering text ini melibatkan data teks yang tidak terstruktur, teknik dalam text mining dapat dijadikan sebagai solusi untuk menemukan kata atau pola yang diinginkan untuk dijadikan kunci dalam proses clustering. Text Mining itu sendiri adalah proses ekstraksi pola berupa informasi dan pengetahuan yang berguna dari sejumlah besar sumber data teks [3]. Proses pada text mining tersebut yang diantaranya adalah case folding, tokenization, filtering, dan stemming memiliki tujuan untuk mereduksi atau mengekstrak data serta mengurangi noise pada data [4]. Data yang diolah dalam proses clustering adalah berupa data berbentuk vector maka diperlukan metode pembobotan kata (term weighting) untuk menghitung frekuensi kemunculan dari setiap term. Dalam hal ini metode yang dipakai dalam pembobotan kata adalah 
Metode Term Frequency (Tf) dan Inverse Document Frequency (Idf).

Digunakannya Algoritma K-Means dalam penelitian ini adalah dikarenakan data inputan yang akan diproses terbilang masih sederhana sehingga lebih cocok menggunakan algoritma $K$-Means serta dilihat dari penelitian sebelumnya dimana Algoritma K-Means berhasil melakukan pengelompokan terhadap dokumen teks. Prilianti dan Wijaya [5] melakukan clustering terhadap skripsi mahasiswa di sebuah Universitas Ma Chung, Algoritma K-Means berhasil melakukan pengelompokan terhadap dokumen-dokumen srkipsi yang ada dengan nilai purity sebesar 76\%, artinya sekitar $76 \%$ dokumen yang telah diolah telah berhasil dikelompokkan dengan benar oleh sistem. Sistem ini diharapkan dapat mengelompokan berita sesuai dengan persamaan yang dimiliki.

\section{Metode Penelitian}

Clustering merupakan algoritma pengelompokkan sejumlah data menjadi kelompok-kelompok data tertentu (cluster) [6], yang bertujuan untuk mengelompokkan data dengan karakteristik yang sama ke suatu wilayah atau kelompok yang sama dan data dengan karakteristik yang berbeda ke wilayah atau kelompok yang lainnya seperti tampak pada Gambar 1:

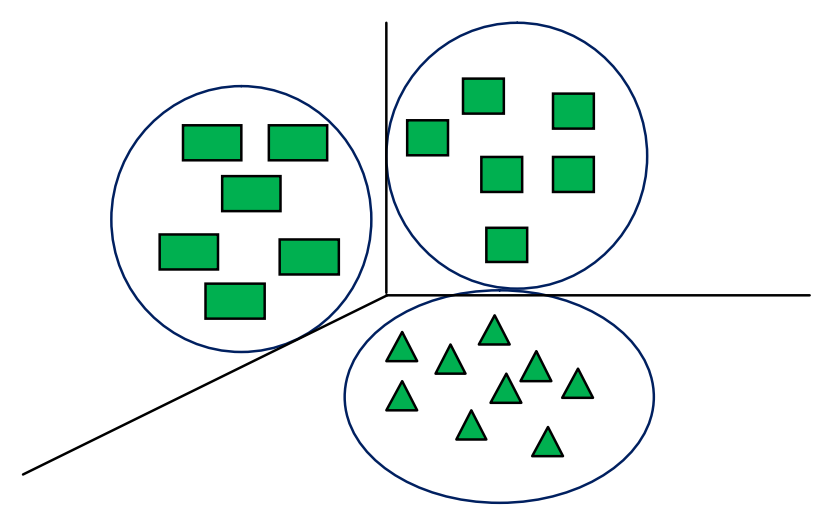

Gambar 1: Contoh pengelompokan berdasarkan bentuk.

Pada Gambar 1: menunjukkan data dikelompokkan sesuai dengan karakteristik bentuk yang dimiliki dimana data tersebut dikelompokkan menjadi tiga kelompok yaitu kelompok dengan bentuk persegi panjang, kotak dan lingkaran.

Dalam perancangan penelitian terdapat beberapa tahapan yang digunakan yaitu sebagai berikut:

\section{A. Pengumpulan Data dan Analisis Kebutuhan}

Dalam pengumpulan Data peneliti melakukan permintaan permohonan data Pemerintah dengan mengirimkan surat permohonan data. Setelah didapatkannya data tersebut, peneliti melakukan analisa kebutuhan untuk mengidentifikasi jenis informasi apa saja yang diperlukan, evaluasi data dan lingkup laporan yang diinginkan. Sumber data yang akan diolah pada proses clustering adalah dari database berita Pemerintah.

\section{B. Preprocessing Dokumen}

Untuk mengolah dokumen yang didapat agar lebih mempermudah dalam proses clustering, dilakukanlah preprocessing dokumen. Preprocessing berfungsi untuk meningkatkan citra, menghilangkan noise, maupun menentukan bagian citra yang akan digunakan dalam tahapan selanjutnya [7]. Preprocessing dokumen terdiri dari case folding yaitu mengubah semua huruf dalam dokumen menjadi huruf kecil dan karakter selain huruf dihilangkan, selanjutnya tokenization atau pemisahan kata, kemudian filtering yaitu penghilangan token berdasarkan stopword, terakhir adalah stemming yaitu pencarian kata dasar dari setiap kata. Pada stemming, algoritma yang digunakan untuk pencarian kata dasarnya adalah Algoritma Nazief \& Adriani. Diagram Alur dari Preprocessing dapat dilihat pada Gambar 2:

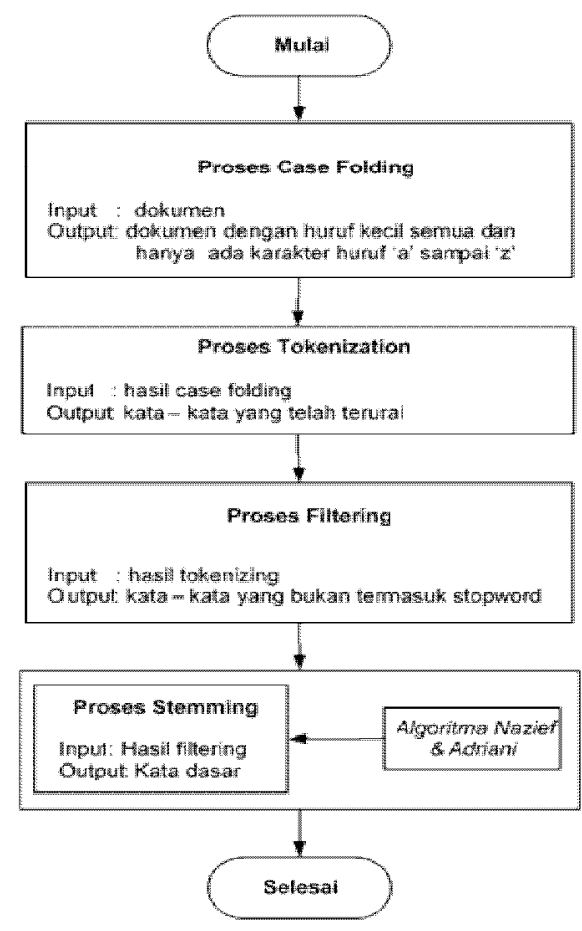

Gambar 2: Diagram alur preprocessing dokumen

\section{Term Weighting}

Setelah dilakukannya preprocessing dokumen (case folding, tokenization, filtering, dan stemming), dimana Tahapan preprocessing akan menghasilkan kumpulan term atau kata, selanjutkan dilakukan proses term weighting yang nantinya akan diberikan bobot atau nilai dimana bobot tersebut mengindikasikan pentingnya sebuah term terhadap dokumen. Penghitungan bobot tiap term dicari pada setiap dokumen bertujuan untuk dapat mengetahui ketersediaan dan kemiripan suatu term di dalam dokumen [8]. Semakin banyak term tersebut muncul pada koleksi dokumen, semakin tinggi nilai atau bobot term tersebut. Setelah tahapan pemberian bobot selesai barulah dilanjutkan ke proses clustering. Dalam Term Weighting, metode yang digunakan dalam melakukan pembobotan adalah metode $T f$-Idf.

Term frequency (Tf) adalah algoritma pembobotan heuristik yang menentukan bobot dokumen berdasarkan kemunculan term [9]. Terdapat empat buah algoritma $T F$ yaitu Raw TF, Logarithmic TF, Binary TF, dan Augmented TF [9], dalam hal ini yang digunakan adalaha Raw Tf. Raw Tf 
DOI: https://doi.org/10.24843/MITE.2018.v17i03.P06

merupakan penentuan bobot suatu dokumen terhadap istilah dengan menghitung frekuensi kemunculan suatu istilah tersebut pada dokumen. Semakin sering sebuah istilah/kata itu muncul, semakin tinggi bobot dokumen untuk istilah/kata tersebut, dan juga sebaliknya.

Inverse Document Frequency (Idf) fokus pada kemunculan term pada keseluruhan koleksi teks. Pada Idf, term yang jarang muncul pada keseluruhan koleksi term dinilai lebih berharga. Inverse Document Frequency (Idf) dihitung dengan menggunakan formula (1).

$$
I d f=\log \left(\frac{\text { jumlah seluruh dokumen dalam koleksi }}{\text { jumlah dokumen yang mengandung istilah }}\right)
$$

Dengan demikian rumus umum untuk perhitungan Tf-Idf adalah penggabungan dari formula perhitungan Raw Tf dengan formula Idf dengan cara mengalikan nilai Term Frequency (Tf) dengan nilai Inverse Document Frequency (Idf).

\section{Proses Clustering}

Pada proses ini dilakukan pengelompokan berita secara otomatis. Setelah dilakukannya preprocessing dokumen yang menghasilkan kata atau term pada setiap dokumen. Selanjutnya dilakukan Term Weighting untuk membobotan setiap term tersebut, dimana nantinya hasil perhitungan dari $T f$-Idf dibentuk suatu vektor. Setelah mendapatkan vektor tersebut dilanjutkan dengan proses clustering dengan menggunakan algoritma $K$-Means, dengan langkah sebagai berikut :

1. Menentukan banyaknya kelompok, dimana kelompok telah ditentukan sebanyak 12 kelompok, yaitu dari 12 program Aksi Bali Mandara.

2. Kemudian objek vektor yang telah didapatkan dari proses pembobotan dialokasikan, dan selanjutnya menentukan centroid nya secara random,

3. Setelah centroid ditentukan maka selanjutnya menghitung jarak antara 2 vektor, dalam hal ini adalah jarak antara centroid dengan objek atau term dengan menggunakan metode Euclidean Distance. Adapun rumus yang digunakan untuk menghitung jarak antara 2 vektor dengan Euclidean Distance [10], seperti dalam formula (2).

$$
\sum_{k=1}^{n}\left(x_{i k}-x_{j k}\right)^{2}
$$

dengan :

dij = tingkat perbedaan

$\mathrm{n}=$ jumlah vektor

xik = vektor citra input

$\mathrm{xjk}=$ vektor citra pembanding / output

4. Jika centroid berubah lagi proses kembali ke langkah 3 dengan penentuan posisi centroid baru dengan menggunakan persamaan (3).

$$
v=\frac{\sum_{i=1}^{n} x_{i}}{n} ; \mathrm{i}=1,2,3, \ldots \mathrm{n}
$$

dengan :

$\mathrm{v}=$ centroid pada cluster

Nyoman Gede Yudiarta: Penerapan Metode Clustering Text ... $\mathrm{xi}=$ objek ke-i

$\mathrm{n}$ = banyaknya objek/jumlah objek yang menjadi anggota cluster

jika posisi centroid tidak berubah lagi berarti proses clustering selesai dan hasil yang didapat adalah pengelompokkan objek dalam kategori tertentu berdasarkan centroid yang terdekat. Berikut ini Ilustrasi dalam proses pembentukan anggota suatu clustering dengan menggunakan Algoritma K-Mean, seperti pada Gambar 3:
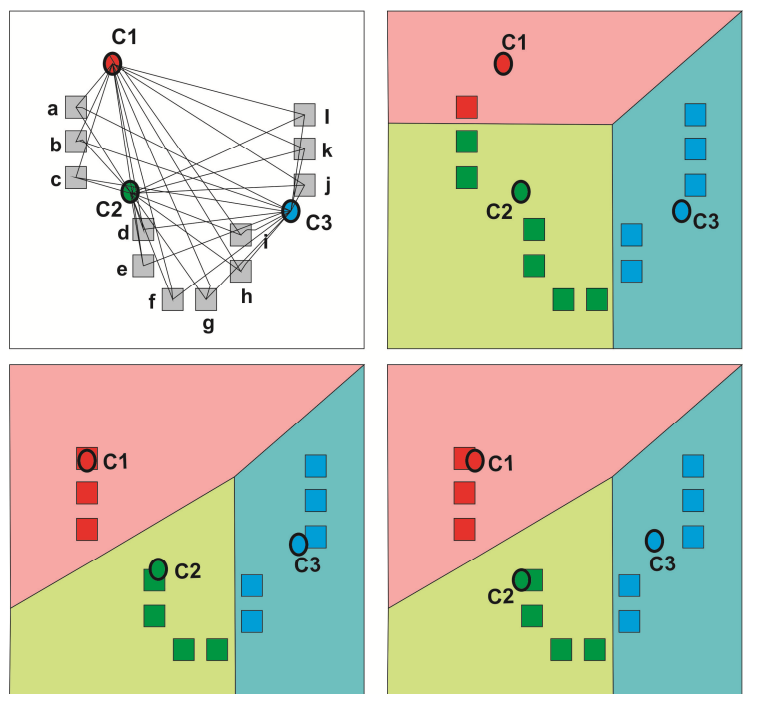

Gambar 3: Ilustrasi Pembentukan Anggota Clustering dengan K-Means

\section{E. Evaluasi}

Setelah melakukan pembuatan sistem, dilakukan evaluasi terhadap hasil dari clustering dengan melakukan perhitungan terhadap Precision, Recall, dan Purity dari cluster yang dihasilkan, apakah sudah tepat kelompok cluster yang dibentuk oleh sistem. Sebelum melakukan penghitungan nilai dari precesion, recall, dan purity akan dilakukan pelabelan manual. Tujuan dilakukannya pelabelan manual adalah sebagai bahan perbandingan untuk perhitungan hasil cluster yang dilakukan oleh sistem, dimana pelabelan manual sebelumnya dilakukan oleh pakar yang membidangi informasi program-program Pemerintah.

\section{HASIL DAN EVALUASI}

\subsection{HASIL}

Tahapan pertama dalam penelitian ini yang harus dilewati adalah tahapan preprocessing dokumen. Pada penelitian ini akan dilakukan perhitungan terhadap 50 data percobaan. Pada 50 judul berita yang di proses, terdapat 654 kata, setelah dilakukan tahapan preprocessing dokumen berupa case folding, tokenization, filtering, dan terakhir stemming total kata menjadi 104 kata dengan total term yang akan diproses lebih lanjut adalah sebanyak 62 kata-kata yang unik. Hasil sistem dapat dilihat pada Gambar 4: 
Gambar 3: Hasil Preprocessing Sistem

berikut term yang didapatkan, setelah hasil preprocessing yang dilakukan oleh sistem adalah pada Tabel 1.

TABEL I

HASIL TERM DARI PREPROCESSING

\begin{tabular}{|l|l|}
\hline No & \multicolumn{1}{|c|}{ Term } \\
\hline 1 & miskin \\
\hline 2 & pendapatan \\
\hline 3 & mea \\
\hline 4 & koperasi \\
\hline 5 & timpang \\
\hline 6 & desa \\
\hline 7 & wisata \\
\hline 8 & sumber \\
\hline 9 & daya \\
\hline 10 & perintah \\
\hline 11 & lapor \\
\hline 12 & periksa \\
\hline 13 & bpk \\
\hline 14 & kinerja \\
\hline 15 & sakit \\
\hline 16 & rumah \\
\hline 17 & pariwisata \\
\hline 18 & budaya \\
\hline 19 & distribusi \\
\hline 20 & akuntabel \\
\hline 21 & disdikpora \\
\hline 22 & pns \\
\hline 23 & disiplin \\
\hline 24 & siwaratri \\
\hline 25 & besakih \\
\hline 26 & umat \\
\hline 27 & tuhan \\
\hline 28 & deklarasi \\
\hline 29 & mental \\
\hline 30 & reformasi \\
\hline 31 & birokrasi \\
\hline & \\
\hline
\end{tabular}

\begin{tabular}{|l|l|}
\hline No & \multicolumn{1}{|c|}{ Term } \\
\hline 32 & pramuka \\
\hline 33 & bina \\
\hline 34 & sadar \\
\hline 35 & muda \\
\hline 36 & jamin \\
\hline 37 & akses \\
\hline 38 & simakrama \\
\hline 39 & pad \\
\hline 40 & bupati \\
\hline 41 & anak \\
\hline 42 & tonggak \\
\hline 43 & puri \\
\hline 44 & krama \\
\hline 45 & ibu \\
\hline 46 & komponen \\
\hline 47 & tani \\
\hline 48 & pohon \\
\hline 49 & studi \\
\hline 50 & rekomendasi \\
\hline 51 & sosialisasi \\
\hline 52 & didik \\
\hline 53 & olahraga \\
\hline 54 & generasi \\
\hline 55 & lintas \\
\hline 56 & agama \\
\hline 57 & akuntansi \\
\hline 58 & akrual \\
\hline 59 & jurnalistik \\
\hline 60 & berita \\
\hline 61 & giat \\
\hline 62 & sejahtera \\
\hline & \\
\hline
\end{tabular}

Tahapan selanjutnya adalah proses prekalian antara Term Frequency (Tf) dengan Inverse Document Frequency (Idf). Berikut hasil proses $T f^{*} I d f$ dapat dilihat pada Tabel 2.

TABEL 2

HASIL $T F * I D F$

\begin{tabular}{|l|r|r|r|r|r|r|}
\hline Doc & $\begin{array}{c}\text { Mis } \\
\text { kin }\end{array}$ & $\begin{array}{c}\text { Penda } \\
\text { patan }\end{array}$ & mea & $\begin{array}{c}\text { koper } \\
\text { asi }\end{array}$ & $\begin{array}{c}\text { s/d } \\
\ldots\end{array}$ & $\begin{array}{c}\text { sejahter } \\
\text { a }\end{array}$ \\
\hline & & & & & & \\
\hline 1 & 0.796 & 1.398 & 0 & 0 & $\ldots$ & 0 \\
\hline 2 & 0.796 & 0 & 0 & 0 & $\ldots$ & 0 \\
\hline 3 & 0 & 0 & 1.699 & 1.398 & $\ldots$ & 0 \\
\hline 4 & 0 & 0 & 0 & 0 & $\ldots$ & 0 \\
\hline 5 & 0 & 1.398 & 0 & 0 & $\ldots$ & 0 \\
\hline 6 & 0 & 0 & 0 & 0 & $\ldots$ & 0 \\
\hline
\end{tabular}

\begin{tabular}{|l|r|r|r|r|r|r|}
\hline 7 & 0 & 0 & 0 & 0 & $\ldots$ & 0 \\
\hline 8 & 0.796 & 0 & 0 & 0 & $\ldots$ & 0 \\
\hline 9 & 0 & 0 & 0 & 0 & $\ldots$ & 0 \\
\hline 10 & 0 & 0 & 0 & 0 & $\ldots$ & 0 \\
\hline 11 & 0 & 0 & 0 & 0 & $\ldots$ & 0 \\
\hline 12 & 0.796 & 0 & 0 & 0 & $\ldots$ & 0 \\
\hline 14 & 0 & 0 & 0 & 0 & $\ldots$ & 0 \\
\hline 15 & 0 & 0 & 0 & 0 & $\ldots$ & 0 \\
\hline 16 & 0.796 & 0 & 0 & 0 & $\ldots$ & 0 \\
\hline 17 & 0 & 0 & 0 & 0 & $\ldots$ & 0 \\
\hline 18 & 0 & 0 & 0 & 0 & $\ldots$ & 0 \\
\hline 19 & 0 & 0 & 0 & 0 & $\ldots$ & 0 \\
\hline 20 & 0 & 0 & 0 & 0 & $\ldots$ & 0 \\
\hline 21 & 0 & 0 & 0 & 0 & $\ldots$ & 0 \\
\hline 22 & 0 & 0 & 0 & 0 & $\ldots$ & 0 \\
\hline 23 & 0 & 0 & 0 & 0 & $\ldots$ & 0 \\
\hline 24 & 0 & 0 & 0 & 0 & $\ldots$ & 0 \\
\hline 25 & 0 & 0 & 0 & 0 & $\ldots$ & 0 \\
\hline 26 & 0 & 0 & 0 & 0 & $\ldots$ & 0 \\
\hline 27 & 0 & 0 & 0 & 1.398 & $\ldots$ & 0 \\
\hline 28 & 0 & 0 & 0 & 0 & $\ldots$ & 0 \\
\hline 29 & 0 & 0 & 0 & 0 & $\ldots$ & 0 \\
\hline 30 & 0.796 & 0 & 0 & 0 & $\ldots$ & 0 \\
\hline 31 & 0 & 0 & 0 & 0 & $\ldots$ & 0 \\
\hline 32 & 0 & 0 & 0 & 0 & $\ldots$ & 0 \\
\hline 33 & 0 & 0 & 0 & 0 & $\ldots$ & 0 \\
\hline 34 & 0 & 0 & 0 & 0 & $\ldots$ & 0 \\
\hline 35 & 0.796 & 0 & 0 & 0 & $\ldots$ & 0 \\
\hline 36 & 0 & 0 & 0 & 0 & $\ldots$ & 0 \\
\hline 37 & 0 & 0 & 0 & 0 & $\ldots$ & 0 \\
\hline 38 & 0 & 0 & 0 & 0 & $\ldots$ & 0 \\
\hline 39 & 0 & 0 & 0 & 0 & $\ldots$ & 0 \\
\hline 40 & 0 & 0 & 0 & 0 & $\ldots$ & 0 \\
\hline 41 & 0 & 0 & 0 & 0 & $\ldots$ & 0 \\
\hline 42 & 0 & 0 & 0 & 0 & $\ldots$ & 0 \\
\hline 43 & 0 & 0 & 0 & 0 & $\ldots$ & 0 \\
\hline 44 & 0 & 0 & 0 & 0 & $\ldots$ & 0 \\
\hline 45 & 0 & 0 & 0 & 0 & $\ldots$ & 0 \\
\hline 46 & 0 & 0 & 0 & 0 & $\ldots$ & 0 \\
\hline 47 & 0 & 0 & 0 & 0 & $\ldots$ & 0 \\
\hline 48 & 0 & 0 & 0 & 0 & $\ldots$ & 0 \\
\hline 49 & 0 & 0 & 0 & 0 & $\ldots$ & 0 \\
\hline 50 & 0.796 & 0 & 0 & 0 & $\ldots$ & 1.699 \\
\hline & & & & & & \\
\hline
\end{tabular}

Setelah proses preprocessing dukumen dan mengubah term menjadi data vektor melalui perkalian $T f^{*} I d f$, maka selanjutnya dilakukan proses pengclusteran dengan menggunakan K-Means. Berikut adalah hasil dari Clustering sistem dengan menggunakan K-Means dapat dilihat pada Gambar 4. 


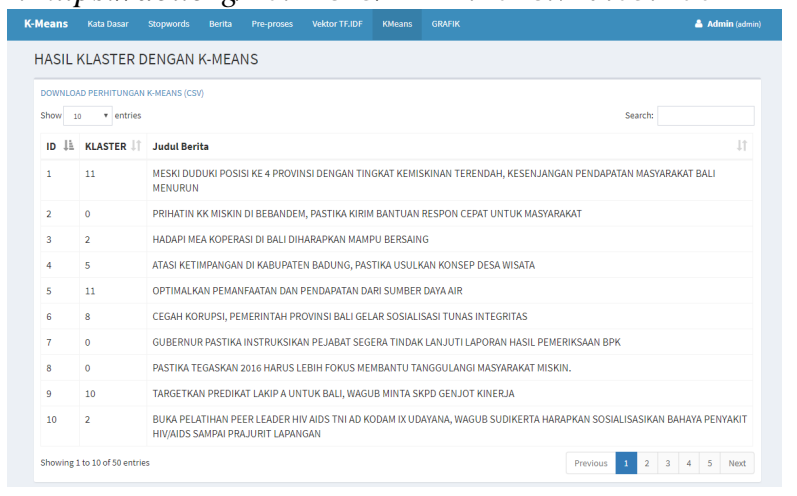

Gambar 3: Hasil Preprocessing Sistem

\subsection{Evaluasi dengan Metode Precision, Recall, dan Purity}

Pengujian precision, recall dan purity dilakukan untuk mengetahui tingkat akurasi dari hasil clustering yang didapatkan oleh sistem. Data yang akan di evaluasi adalah hasil clustering dengan jumlah data : 50, 100, 200, 300, 400, dan 500. Digunakannya data tersebut untuk melihat perbandingan dari hasil clustering yang didapat oleh sistem pada jumlah data yang berbeda. Sebelum masuk ke pengujian menggunakan metode precision, recall dan purity terlebih dahulu dilakukan pemberian label manual oleh Pemerintah. Berikut perbandingan pelabelan pada pengujian 50 data yang dilakukan oleh Pemerintah dengan cluster yang dilakukan oleh sistem jika dikelompokan sesuai cluster nya, maka didapatkan hasil seperti pada Tabel 3.

TABEL 3

PENGELOMPOKAN HASIL CLUSTER 50 DATA

\begin{tabular}{|c|c|l|l|}
\hline Cluster & $\begin{array}{c}\text { Banyaknya } \\
\text { Judul Berita }\end{array}$ & \multicolumn{1}{|c|}{ Kategori } \\
\hline Cluster 0 & 8 judul berita & Bidang Sosial \\
\hline Cluster 1 & 2 judul berita & Bidang Perekonomian \\
\hline Cluster 2 & 9 judul berita & Bidang Kesehatan \\
\hline Cluster 3 & 1 judul berita & $\begin{array}{l}\text { Bidang Lingkungan dan } \\
\text { Pertanian }\end{array}$ \\
\hline Cluster 4 & 4 judul berita & $\begin{array}{l}\text { Bidang Seni Budaya dan } \\
\text { Pariwisata }\end{array}$ \\
\hline Cluster 5 & 3 judul berita & Bidang Pendidikan dan Olah \\
\hline Cluster 6 & 4 judul berita & $\begin{array}{l}\text { Bidang Pemuda dan } \\
\text { Raga }\end{array}$ \\
\hline Cluster 7 & 3 judul berita & Bidang Demokrasi dan HAM \\
\hline Cluster 8 & 10 judul berita & $\begin{array}{l}\text { Bidang Keamanan } \\
\text { Ketertiban Masyarakat }\end{array}$ \\
\hline Cluster 9 & 1 judul berita & Bidang Infrastruktur \\
\hline Cluster 10 & 2 judul berita & $\begin{array}{l}\text { Bidang Pemberdayaan } \\
\text { Perempuan }\end{array}$ \\
\hline Cluster 11 & 3 judul berita & $\begin{array}{l}\text { Bidang Ekonomi Kerakyatan } \\
\text { dan Ketenagakerjaan }\end{array}$ \\
\hline
\end{tabular}

Dalam hal ini kategori dari setiap cluster akan ditentukan oleh peneliti, dikarenakan sistem tidak mengetahui kategori dari setiap cluster, sistem hanya melakukan pengclusteran dari setiap judul yang telah ditentukan. Untuk mempermudah dalam menghitung nilai precision dan recall maka akan ditelusuri data yang relevan dan yang tidak relevan pada data yang telah di cluster. Dapat dilihat pada tabel 4.

Nyoman Gede Yudiarta: Penerapan Metode Clustering Text ...
TABEL 4

HASIL PENELUSURAN CLUSTER 50 DATA

\begin{tabular}{|c|c|c|c|c|c|}
\hline Cluster & $\begin{array}{c}\text { Rele } \\
\text { Van } \\
\text { (a) }\end{array}$ & $\begin{array}{c}\text { Tidak } \\
\text { Relevan } \\
\text { (b) }\end{array}$ & $\begin{array}{c}\text { Ditemu } \\
\text { kan } \\
(\mathbf{a}+\mathbf{b})\end{array}$ & $\begin{array}{c}\text { Tidak } \\
\text { Ditemu } \\
\text { kan } \\
\text { (d) }\end{array}$ & $\begin{array}{c}\text { Total } \\
\text { Releva } \\
\text { n } \\
\text { dalam } \\
\text { Koleks } \\
\text { i } \\
(\mathbf{a}+\mathbf{d}) \\
\end{array}$ \\
\hline Cluster 0 & 7 & 1 & 8 & 0 & 7 \\
\hline Cluster 1 & 2 & 0 & 2 & 6 & 8 \\
\hline Cluster 2 & 8 & 1 & 9 & 0 & 8 \\
\hline Cluster 3 & 1 & 0 & 1 & 0 & 1 \\
\hline Cluster 4 & 4 & 0 & 4 & 1 & 5 \\
\hline Cluster 5 & 1 & 2 & 3 & 1 & 2 \\
\hline Cluster 6 & 2 & 2 & 4 & 2 & 4 \\
\hline Cluster 7 & 3 & 0 & 3 & 0 & 3 \\
\hline Cluster 8 & 8 & 2 & 10 & 0 & 8 \\
\hline Cluster 9 & 1 & 0 & 1 & 0 & 1 \\
\hline Cluster 10 & 1 & 1 & 2 & 0 & 1 \\
\hline Cluster 11 & 1 & 2 & 3 & 1 & 2 \\
\hline Total & 39 & 11 & 50 & 11 & 50 \\
\hline
\end{tabular}

Berikut nilai Precision dan Recall dari masing masing cluster dapat dilihat pada Tabel 5 dan Tabel 6.

TABEL 5

HASIL PRECISION 50 DATA

\begin{tabular}{|l|l|r|}
\hline Cluster & \multicolumn{1}{|c|}{ Kategori } & \multicolumn{1}{|c|}{ Precision } \\
\hline Cluster 0 & Bidang Sosial & $87.50 \%$ \\
\hline Cluster 1 & Bidang Perekonomian & $100.00 \%$ \\
\hline Cluster 2 & Bidang Kesehatan & $88.89 \%$ \\
\hline Cluster 3 & Bidang Lingkungan dan Pertanian & $100.00 \%$ \\
\hline Cluster 4 & Bidang Seni Budaya dan Pariwisata & $100.00 \%$ \\
\hline Cluster 5 & Bidang Pendidikan & $33.33 \%$ \\
\hline Cluster 6 & Bidang Pemuda dan Olah Raga & $50.00 \%$ \\
\hline Cluster 7 & Bidang Demokrasi dan HAM & $100.00 \%$ \\
\hline Cluster 8 & $\begin{array}{l}\text { Bidang Keamanan dan Ketertiban } \\
\text { Masyarakat }\end{array}$ & $80.00 \%$ \\
\hline Cluster 9 & Bidang Infrastruktur & $100.00 \%$ \\
\hline Cluster 10 & Bidang Pemberdayaan Perempuan & $50.00 \%$ \\
\hline Cluster 11 & $\begin{array}{l}\text { Bidang Ekonomi Kerakyatan dan } \\
\text { Ketenagakerjaan }\end{array}$ & $33.33 \%$ \\
\hline \multicolumn{2}{|c|}{ Rata-rata } & $76.92 \%$ \\
\hline
\end{tabular}

Dilihat dari tabel diatas, bahwa sebagian besar setiap cluster memiliki presisi yang bagus, artinya pada satu cluster, data benar yang didapat lebih banyak daripada data yang salah, hanya beberapa cluster yang memiliki hasil presisi yang kurang yaitu cluster 5 dan cluster 11 .

TABEL 6

HASIL RECALL 50 DATA

\begin{tabular}{|l|l|r|}
\hline Cluster & \multicolumn{1}{|c|}{ Kategori } & \multicolumn{1}{c|}{ Recall } \\
\hline Cluster 0 & Bidang Sosial & $100.00 \%$ \\
\hline Cluster 1 & Bidang Perekonomian & $25.00 \%$ \\
\hline Cluster 2 & Bidang Kesehatan & $100.00 \%$ \\
\hline Cluster 3 & Bidang Lingkungan dan Pertanian & $100.00 \%$ \\
\hline Cluster 4 & Bidang Seni Budaya dan Pariwisata & $80.00 \%$ \\
\hline Cluster 5 & Bidang Pendidikan & $50.00 \%$ \\
\hline Cluster 6 & Bidang Pemuda dan Olah Raga & $50.00 \%$ \\
\hline Cluster 7 & Bidang Demokrasi dan HAM & $100.00 \%$ \\
\hline
\end{tabular}

p-ISSN:1693 - 2951; e-ISSN: 2503-2372 


\begin{tabular}{|c|l|r|}
\hline Cluster 8 & $\begin{array}{l}\text { Bidang Keamanan dan Ketertiban } \\
\text { Masyarakat }\end{array}$ & $100.00 \%$ \\
\hline Cluster 9 & Bidang Infrastruktur & $100.00 \%$ \\
\hline Cluster 10 & Bidang Pemberdayaan Perempuan & $100.00 \%$ \\
\hline Cluster 11 & $\begin{array}{l}\text { Bidang Ekonomi Kerakyatan dan } \\
\text { Ketenagakerjaan }\end{array}$ & $50.00 \%$ \\
\hline \multicolumn{2}{|r|}{ Rata-rata } & $79.58 \%$ \\
\hline
\end{tabular}

Pada Tabel 6. dapat dilihat bahwa dalam hal ini sistem berhasil mengelompokan judul berita ke dalam kelompok yang tepat, hanya 1 cluster yang kurang ditemukan sesuai dengan total yang harus ditemukan yaitu pada cluster 1 .

Berikut hasil perbandingan nilai rata-rata dari precision dan recall serta nilai purity dari 50 data, 100 data, 200 data, 300 data, 400 data, dan 500 data dapat dilihat pada Tabel 7 .

TABEL 7

Hasil Perbandingan Nilai PRECision, RECALL, DAN PURITY

\begin{tabular}{|c|c|r|r|r|}
\hline No & Data & Precision & Recall & \multicolumn{1}{c|}{ Purity } \\
\hline 1 & 50 & $76,92 \%$ & $79,58 \%$ & 0,78 \\
\hline 2 & 100 & $71,84 \%$ & $72,38 \%$ & 0,79 \\
\hline 3 & 200 & $71,17 \%$ & $63,26 \%$ & 0,78 \\
\hline 4 & 300 & $76,44 \%$ & $70,73 \%$ & 0,83 \\
\hline 5 & 400 & $72,27 \%$ & $65,92 \%$ & 0,81 \\
\hline 6 & 500 & $70.00 \%$ & $66,03 \%$ & 0,79 \\
\hline
\end{tabular}

Pada Tabel 7. dapat dilihat bahwa pada pengujian 50 data memiliki tingkat rata-rata precision dan recall paling tinggi yaitu $76,92 \%$ untuk precision nya sedangkan untuk recall nya sebesar 79,58\% dari pengujian data yang lainnya. ini berarti bahwa penempatan data pada setiap cluster nya di pengujian 50 data kebanyakan sudah tepat. Sedangkan untuk Purity nya nilai yang paling tinggi adalah pada pengujian 300 data yaitu sebesar 0,83 .

\section{KESIMPULAN}

Kesimpulan yang dapat ditarik dari penelitian ini adalah sebagai berikut :

1. Penentuan centroid awal (titik pusat) pada Algoritma $K$ Means sangat berpengaruh pada hasil cluster, dimana centroid awal tersebut ditentukan secara acak, sehingga terkadang tingkat keakuratannya kurang baik, maka dari itu perlu dilakukan proses uji coba berkali kali agar mendapatkan hasil cluster yang baik.

2. Pada beberapa kelompok data yang diuji, pengujian 50 data memiliki rata - rata persentase nilai Precision dan Recall yang paling besar yaitu 76,92\% untuk precision dan sebesar $79,58 \%$ untuk recall nya. Sedang kan untuk nilai purity nya yang terbesar terdapat pada pengujian 300 data yaitu sebesar 0,83. Dengan demikian dapat dikatakan bahwa Algoritma K-Means mampu mengelompokkan dokumen ke dalam 12 kelompok, serta melakukan pengelompokan dokumen dalam jumlah yang banyak.

\section{REFERENSI}

[1] Herny Februariyanti Dan Dwi Budi Santoso, 2017, "Hierarchical Agglomerative Clustering Untuk Pengelompokan Skripsi Mahasiswa," Prosiding SINITAK 2017, ISBN: 978-602-8557-20-7.

[2] Pivin Suwrmayanti, I Ketut Gede Darma Putra, I Nyoman Satya Kumara, "Optimasi Pusat Cluster K-Prototype dengan Algoritma Genetika," Teknologi Elektro, Vol. 13 No. 2 Juli-Desember 2014.
[3] PenambanganTeks, https://id.wikipedia.org/ (diakses tanggal 27 Juni 2015).

[4] Thopo Martha Akbar, Angelina Prima Kurniati, Moch Arif Bijaksana, 2012 "Analisis Perbandingan Metode Pembobotan Kata Tf.Idf Dan Tf.Rf Terhadap Performansi Kategorisasi Teks".

[5] Kestrilia Rega Prilianti, Hendra Wijaya, 2014, "Aplikasi Text Mining Untuk Automasi Penentuan Tren Topik Skripsi Dengan Metode KMeans Clustering," Jurnal Cybermatika, Vol. 2 No. 1.

[6] Mardiani, 2014, " Perbandingan Algoritma K-Means dan EM untuk Clusterisasi Nilai Mahasiswa Berdasarkan Asal Sekolah," Citec Journal, Vol. 1, No. 4, ISSN: 2354-5771.

[7] Ni Putu Sutramiani, I Ketut Gede Darma Putra, Made Sudarma, "Local Adaptive Thresholding pada Preprocessing Citra Lontar Aksara Bali," Jurnal Teknologi Elektro, Vol.14, No.1,Januari-Juni 2015.

[8] Pausta Yugianus, Harry Soekotjo Dachlan, dan Rini Nur Hasanah, 2013 "Pengembangan Sistem Penelusuran Katalog Perpustakaan Dengan Metode Rocchio Relevance Feedback", EECCIS Vol. 7, No. 1, Juni 2013.

[9] Sendhy Rachmat Wurdianarto, Sendi Novianto, Umi Rosyidah, 2014, Perbandingan Euclidean Distance Dengan Canberra Distance Pada Face Recognition, Techno.COM, Vol. 13, No. $1: 31-37$

[10] Ediyanto, Muhlasah Novitasari Mara, Neva Satyahadewi, 2013, "Pengklasifikasian Karakteristik Dengan Metode K-Means Cluster Analysis," Buletin Ilmiah Mat. Stat. dan Terapannya (Bimaster) Volume 02 , No. 2, Hal 133 - 136 